\title{
Bacteriostatic and Bactericidal Mechanism of Novel Compound Isolated from Ethyl Acetate Stem Bark Extract of Spondias mombin Using Biomarker Repressor LexA gene on Escherichia coli and Bacillus subtilis
}

Oludare Temitope Osuntokun ${ }^{1^{*}}$ and Olaposi I Omotuyi ${ }^{2}$

${ }^{1}$ Faculty of Science, Department of Microbiology, Adekunle Ajasin University, Akungba Akoko, Ondo State, Nigeria

${ }^{2}$ Centre for Biocomputing and Drug Development, Adekunle Ajasin University, Nigeria

"Corresponding author: Oludare Temitope Osuntokun, Faculty of Science, Department of Microbiology, Adekunle Ajasin University, Akungba Akoko, P.M.B 001, Ondo State, Nigeria, Tel: +234 705789 0597; E-mail: osuntokun4m@yahoo.com

Rec Date: March 01, 2018, Acc Date: November 12, 2018, Pub Date: November 14, 2018

Copyright: (c) 2018 Osuntokun OT, et al. This is an open-access article distributed under the terms of the Creative Commons Attribution License, which permits unrestricted use, distribution, and reproduction in any medium, provided the original author and source are credited.

\begin{abstract}
The purpose of the research work is to determine the mechanism of action of novel compound $\left(A_{1}\right.$ Epigallocatechin, Epicatechin and Stigmasterol Phytosterol (Synergy)), $\left(A_{3}\right.$-Aspidofractinine-3-methanol) and $\left(F_{3^{-}}\right.$ Terephthalic acid, dodecyl 2-ethylhexyl ester) against two selected clinical organism by Repressor LexA gene expression. Clinical microorganisms were cultured and sub-culturing in Department of Microbiology and Centre for Biocomputing and Drug Development (CBDD), Adekunle Ajasin University, Akungba Akoko, Ondo-state, a 12 hours old culture of each microorganism was re-suspended in Spondias mombin extract at $1000 \mu \mathrm{g} \mathrm{mL}$ in a total volume of $500 \mu \mathrm{l}$ for $0,15,30,45,60$, and 180 minutes. The bacteria cells were pelleted by centrifugation at $5000 \mathrm{~g}$ for 5 minutes, to isolate their DNA. Total RNA was quantified using spectrophotometric absorbance at $260 \mathrm{~nm}$. DNA was removed with Turbo DNA-free (Ambion, Inc.) and removal of DNA from the RNA samples was performed using DNA-free ${ }^{\mathrm{TM}}$ DNA Removal Kit. Reverse transcription-PCR reaction was performed in a $15.0 \mu \mathrm{l}$ final volume $1 \mu \mathrm{l}$ template cDNA ( 40 ng) was combined with $1.0 \mu \mathrm{l}$ of forward primer $(5 \mathrm{nM}), 1.0 \mu \mathrm{l}$ of reverse primer $(5 \mathrm{nM}), 4.5 \mathrm{ml}$ nuclease-free water and $7.5 \mu \mathrm{l}$ of Taq $2 \mathrm{X}$ Master Mix. The master mix and the aliquot were assessed by Polymerase Chain Reaction products (amplicons) and electrophoresed in $0.5 \%$ of agarose gel using $0.5 \times$ TBE buffer $(2.6 \mathrm{~g}$ of Tris base, $5 \mathrm{~g}$ of Tris boric acid and $2 \mathrm{ml}$ of $0.5 \mathrm{M}$ EDTA and adjusted to $\mathrm{pH} 8.3$ with the sodium hydroxide pellet) with $0.5 \mu \mathrm{l}$ ethidum bromide. It was observed that, in 30 minutes time interval, the mechanism of action is bacteriostatic on $B$. subtilis, an SOS regulum was activated by $B$. subtilis at 180 minutes, to resuscitate the dying cell of $B$. subtilis. The mechanism of action of biomarker repressor LexA gene on isolated novel compounds using $E$. coli as the test bacteria. It was observed that isolated novel compounds has bactericidal action on $E$. coli at 180 minutes of administration using repressor LexA gene to stimulate death phases of growth. The novel compounds disrupt the SOS regulun, the E. coli cells were complete destroyed. LexA has rapid progress to sequence death phase with time interval, this led to the death of the $E$. coli cell, it can be deduced that, this method can be used to program the death of bacteria cell in case of a recalcitrant resistance infections in the treatment of severe cough, diarrhea, dysentery, haemorrhoids, gonorrhoea and leucorrhea.
\end{abstract}

Keywords: Epigallocatechin; Epicatechin; Stigmasterol phytosterol; Repressor LexA

\section{Introduction}

Spondias mombin Linn is a small tree that grows up to $30 \mathrm{~m}$ high and $1.5 \mathrm{~m}$ in height, moderately buttressed; bark thick, corky, deeply fissured, slash pale pink, darkening rapidly, branches low, branchlets glabrous; leaves pinnate, leaflets 5-8 opposite pairs with a terminal leaflet. It belongs to the family Anacardiaceae and the fruits have a sharp, acid taste [1]. The roots are also used as febrifuge and stem bark is used as a purgative and in local applications for leprosy. The stem bark decoction is also used in the treatment of severe cough and used for diarrhea, dysentery, haemorrhoids and a treatment for gonorrhoea and leucorrhea [2]. The decoction of the astringent bark is believed to expel calcifications from the bladder [3].

A report showed that the stem bark contains a certain amount of tannin, alkaloid and flavonoid, this explains the reason why the dry pulverized stem bark is applied as a dressing to a wound [4]. The stem bark is a remedy for diarrhea and dysentery. The gum is employed as an expectorant and to expel tapeworms [5,6]. A leaf infusion is a common cough remedy or used as a laxative for fever with constipation and the pounded leaves of $S$. mombin is used as an eye lotion and the juice pressed from young, warm leaves is given to children for stomach troubles [7]. A tea made from the flowers and leaves is taken to relieve stomach ache, biliousness, urethritis, cystitis and eye and throat inflammations. A decoction of the root is used as purgative $[8,9]$.

Repressor $\operatorname{Lex} A$ is a transcriptional repressor SOS response genes coding primarily for error-prone DNA polymerases, DNA repair enzymes and cell division inhibitors [10]. LexA forms de facto a twocomponent regulatory system with $\operatorname{Rec} A$, which senses DNA damage at stalled replication forks, forming monofilaments and acquiring an active conformation capable of binding to $\operatorname{Lex} A$ and causing $\operatorname{Lex} A$ to cleave itself, in a process called autoproteolysis [11]. DNA damage can be inflicted by the action of antibiotics plant extract like Spondias mombin [12] of potential clinical interest is the induction of the SOS response by antibiotics. Bacteria require topoisomerases such as DNA gyrase or topoisomerase IV for DNA replication. 
Citation: Osuntokun OT, Omotuyi OI (2018) Bacteriostatic and Bactericidal Mechanism of Novel Compound Isolated from Ethyl Acetate Stem Bark Extract of Spondias mombin Using Biomarker Repressor LexA gene on Escherichia coli and Bacillus subtilis. J Mol Biomark Diagn 9: 405. doi:10.4172/2155-9929.1000405

Page 2 of 7

Antibiotics and plant extract like Spondias mombin are able to prevent the action of these molecules by attaching themselves to the gyrase-DNA complex, leading to replication fork stall and the induction of the SOS response. The expression of error-prone polymerases under the SOS response increases the basal mutation rate of bacteria. While mutations are often lethal to the cell, they can also enhance survival. In the specific case of topoisomerases, some bacteria have mutated one of their amino acids so that the plant extract can only create a weak bond to the topoisomerase. This is one of the methods that bacteria use to become resistant to plant extract. Plant extract treatment can therefore potentially lead to the generation of mutations that may render bacteria resistant to plant extract.

In addition, plant extract has also been shown to induce via the SOS response dissemination of virulence factors [13] and antibiotic resistance determinants, as well as the activation of integron integrases [14] potentially increasing the likelihood of acquisition and dissemination of antibiotic resistance by bacteria. Lex $A$ biomarker contains a DNA binding domain. The winged HTH motif of LexA is a variant form of the helix-turn-helix DNA binding motif it is usually located at the N-terminus of the protein [15]. The mode of action of Represses $\operatorname{din} A, \operatorname{din} B, \operatorname{din} C, \operatorname{rec} A$ genes and itself by binding to the 14 bp palindromic sequence 5'-CGAACNNNNGTTCG-3'; some genes have a tandem consensus sequence and their binding is cooperative. In the presence of single-stranded DNA, RecA interacts with LexA causing an autocatalytic cleavage which disrupts the DNA-binding part of $\operatorname{Lex} A$, leading to derepression of the SOS regulon and eventually DNA repair; autocleavage is maximal at $\mathrm{pH} 11$ in the absence of $\operatorname{Rec} A$ and ssDNA [16].

\section{Materials and Methods}

\section{Isolation of clinical microorganisms}

Clinical microorganisms were isolated and cultured from Department of Microbiology and Centre for Biocomputing and Drug Development (CBDD), Adekunle Ajasin University, Akungba Akoko, Ondo-state, Nigeria. High quality RNA was isolated from the selected test organisms (E. coli, B. substils, A. flavus) using a modified hot SDS/hot phenol method [17].

\section{Isolation of RNA}

A 12 hours old culture of each microorganism was re-suspended in plant extract at $1000 \mu \mathrm{g} \mathrm{mL}$ in a total volume of $500 \mu \mathrm{l}$ for $0,15,30,45$, 60 , and 180 minutes. The cells were pelleted by centrifugation at $5000 \mathrm{~g}$ for 5 minutes. The pellets were rinsed twice in phosphate buffer saline (PBS). Then $1 / 10$ volume of $95 \%$ ethanol plus $5 \%$ saturated phenol were added to the pellets to stabilise cellular RNA. The cells were then re-harvested by centrifugation $\left(8200 \mathrm{~g}, 4^{\circ} \mathrm{C}\right.$ and 2 minutes). The supernatant was aspirated and pellets re-suspended in $800 \mu \mathrm{l}$ of lysis buffer (10 mM Tris, adjusted to $\mathrm{pH} 8.0$ with $\mathrm{HCl}, 1 \mathrm{mM}$ EDTA) and $8.3 \mathrm{U} / \mathrm{ml}$ Ready-Lyse ${ }^{\mathrm{TM}}$ lysozyme solution. After the pellets were resuspended, $80 \mu \mathrm{l}$ of a $10 \%$ SDS solution was added, mixed and incubated for 2 minutes at $64^{\circ} \mathrm{C}$. Then $88 \mu \mathrm{l}$ of $1 \mathrm{M} \mathrm{NaOAc}(\mathrm{pH} \mathrm{5.2)}$ was mixed with the lysate followed by an equal volume of water and saturated phenol was added. This was incubated at $64^{\circ} \mathrm{C}$ for 6 minutes while inverting the tubes every 40 seconds. The aqueous phase was separated following centrifugation at $21,000 \mathrm{~g}$ for 10 minutes at $4^{\circ} \mathrm{C}$. The RNA was precipitated from the aqueous layer using $1 / 10$ volume of $3 \mathrm{M} \mathrm{NaOAc}$ (pH 5.2), $1 \mathrm{mM}$ EDTA and 2 volumes cold EtOH and centrifugation at $21,000 \mathrm{~g}$ for 25 minutes at $4^{\circ} \mathrm{C}$. Pellets were washed with ice cold $80 \% \mathrm{EtOH}$ and centrifuged at $21,000 \mathrm{~g}$ for 5 minutes at $4^{\circ} \mathrm{C}$. The ethanol was carefully removed and the pellets were air dried for 20 minutes. The pellets from each split sample were re-suspended in a total of $100 \mu \mathrm{l}$ of RNase-free water and combined into one microfuge [18] (Table 1).

\section{Synthesis of convertible}

Total RNA was quantified using spectrophotometric absorbance at $260 \mathrm{~nm}$ DNA was removed with Turbo DNA-free (Ambion, Inc.). Removal of DNA from the RNA samples was performed using DNAfree $^{\mathrm{TM}}$ DNA Removal Kit (ThermoFisher) following manufacturer's protocol. Purified DNA-free RNA was converted to cDNA immediately using ProtoScript ${ }^{\circ}$ First Strand cDNA Synthesis Kit (NEB). The cDNA was diluted to a final volume of $286 \mu \mathrm{l}$ and stored at $4^{\circ} \mathrm{C}$ [19].

\section{PCR protocol}

Reverse Transcription-PCR reaction was performed in a $15.0 \mu \mathrm{l}$ final volume. Briefly, $1 \mu \mathrm{l}$ template cDNA ( 40 ng) was combined with 1.0 $\mu \mathrm{l}$ of forward primer $(5 \mathrm{nM}), 1.0 \mu \mathrm{l}$ of reverse primer $(5 \mathrm{nM}), 4.5 \mathrm{ml}$ nuclease-free water and $7.5 \mu \mathrm{l}$ of Taq $2 \mathrm{X}$ Master Mix. Thermo cycling was performed by 40 cycles at $95^{\circ} \mathrm{C}$ for 15 seconds, $60^{\circ} \mathrm{C}$ for 15 seconds and $72^{\circ} \mathrm{C}$ for 15 seconds (Table 2). Analysis of the PCR products was performed using 1.5\% agarose gel solution in TBE buffer and visualisation was enabled by soaking gel in ethidium bromide solution for 10 minutes and UV-transilluminator. The data obtained were analyzed using Graph pad prism version 6.01 descriptions and frequency. Statistics were generated to describe the diameter of inhibition, quantitative phytochemical constituent and toxicological parameter to test for the level of significance [20].

\section{Gel electrophoresis}

Assessment of Polymerase Chain Reaction products (amplicons) were electrophoresed in $0.5 \%$ of agarose gel using $0.5 \times$ TBE buffer $(2.6$ $\mathrm{g}$ of Tris base, $5 \mathrm{~g}$ of Tris boric acid and $2 \mathrm{ml}$ of $0.5 \mathrm{M}$ EDTA and adjusted to $\mathrm{pH} 8.3$ with the sodium hydroxide pellet) with $0.5 \mu \mathrm{l}$ ethidum bromide. The expression product was visualized as bands by UV-transilluminator.

\section{Results}

Bacteriostatic and bactericidal mechanism of action of $\mathrm{A}_{1}$ (Epigallocatechin, Epicatechin and Stigmasterol phytosterol(synergy), $\quad \mathrm{A}_{3}$ (Aspidofractinine-3-methanol) and $\mathrm{F}_{3}$ (Terephthalic acid, dodecyl 2-ethylhexyl ester) isolated from ethyl acetate extract of Spondias mombin using gene expression LexA on Escherichia coli and Bacillus subtilis.

Figure 1 shows the mechanism of action of isolated compounds $A_{1}$, $\mathrm{A}_{3}$ and $\mathrm{F}_{3}$ from the ethyl acetate stem bark extract of Spondias mombin. The mechanism of action was demonstrated with the selected biomarker LevA repressor gene against $B$. subtilis. It was observed that at 30 minutes, the mechanism of action is bacteriostatic action on the test organism (B. subtilis), but an SOS regulum was activated by $B$. subtilis at 180 minutes, to resuscitate the dying cell of $B$. subtilis. Bacteriostatic action were observed at $1000 \mu \mathrm{g} / \mathrm{mL}$ in Figures $1-4$ in compound $\mathrm{A}_{3}$ and $\mathrm{F}_{3}$ on B. subtilis. 
Citation: Osuntokun OT, Omotuyi OI (2018) Bacteriostatic and Bactericidal Mechanism of Novel Compound Isolated from Ethyl Acetate Stem Bark Extract of Spondias mombin Using Biomarker Repressor LexA gene on Escherichia coli and Bacillus subtilis. J Mol Biomark Diagn 9: 405. doi:10.4172/2155-9929.1000405

Page 3 of 7

\begin{tabular}{|c|c|}
\hline Steps & Procedure \\
\hline 1 & Test Organisms (E. coli, B. substils) using a modified hot SDS/hot phenol method (12 hours old culture). \\
\hline 2 & Microorganism was re-suspended in plant extract at $1000 \mu \mathrm{g} \mathrm{mL}$ in a total volume of $500 \mu \mathrm{l}$ for $0,15,30,45,60$, and $180 \mathrm{minutes}$. \\
\hline 2 & The cells were pelleted by centrifugation at $5000 \mathrm{~g}$ for 5 minutes, Pellets were rinsed twice in phosphate buffer saline (PBS). \\
\hline 4 & $1 / 10$ volume of $95 \%$ ethanol plus $5 \%$ saturated phenol were added to the pellets to stabilise cellular RNA. \\
\hline 5 & The cells were then re-harvested by centrifugation $\left(8200 \mathrm{~g}, 4^{\circ} \mathrm{C}\right.$ and 2 minutes). \\
\hline 6 & $\begin{array}{l}\text { The supernatant was aspirated and pellets resuspended in } 800 \mu \mathrm{l} \text { of lysis buffer ( } 10 \mathrm{mM} \text { Tris, adjusted to } \mathrm{pH} 8.0 \mathrm{with} \mathrm{HCl}, 1 \mathrm{mM} \text { EDTA) and } \\
8.3 \mathrm{U} / \mathrm{ml} \text { Ready-LyseTM Lysozyme Solution. }\end{array}$ \\
\hline 7 & Pellets were resuspended, $80 \mu \mathrm{l}$ of a $10 \%$ SDS solution was added, mixed and incubated for 2 minutes at $64^{\circ} \mathrm{C}$. \\
\hline 8 & $88 \mu \mathrm{l}$ of $1 \mathrm{M} \mathrm{NaOAc}(\mathrm{pH} 5.2)$ was mixed with the lysate followed by an equal volume of water and saturated phenol was added. \\
\hline 9 & Incubated at $64^{\circ} \mathrm{C}$ for 6 minutes while inverting the tubes every 40 seconds. \\
\hline 10 & Aqueous phase was separated following centrifugation at $21,000 \mathrm{~g}$ for 10 minutes at $4^{\circ} \mathrm{C}$. \\
\hline 11 & $\begin{array}{l}\text { RNA was precipitated from the aqueous layer using } 1 / 10 \text { volume of } 3 \mathrm{M} \mathrm{NaOAc}(\mathrm{pH} 5.2), 1 \mathrm{mM} \text { EDTA and } 2 \text { volumes cold EtOH and } \\
\text { centrifugation at } 21,000 \mathrm{~g} \text { for } 25 \text { minutes at } 4^{\circ} \mathrm{C} \text {. }\end{array}$ \\
\hline 12 & Pellets were washed with ice cold $80 \% \mathrm{EtOH}$ and centrifuged at $21,000 \mathrm{~g}$ for 5 minutes at $4^{\circ} \mathrm{C}$. \\
\hline 13 & $\begin{array}{l}\text { Ethanol was carefully removed and the pellets were air dried for } 20 \text { minutes. The pellets from each split sample were re-suspended in a total } \\
\text { of } 100 \mu \text { l of RNase-free water and combined into one microfuge. }\end{array}$ \\
\hline
\end{tabular}

Table 1: Steps for isolation of RNA from bacterial cell.
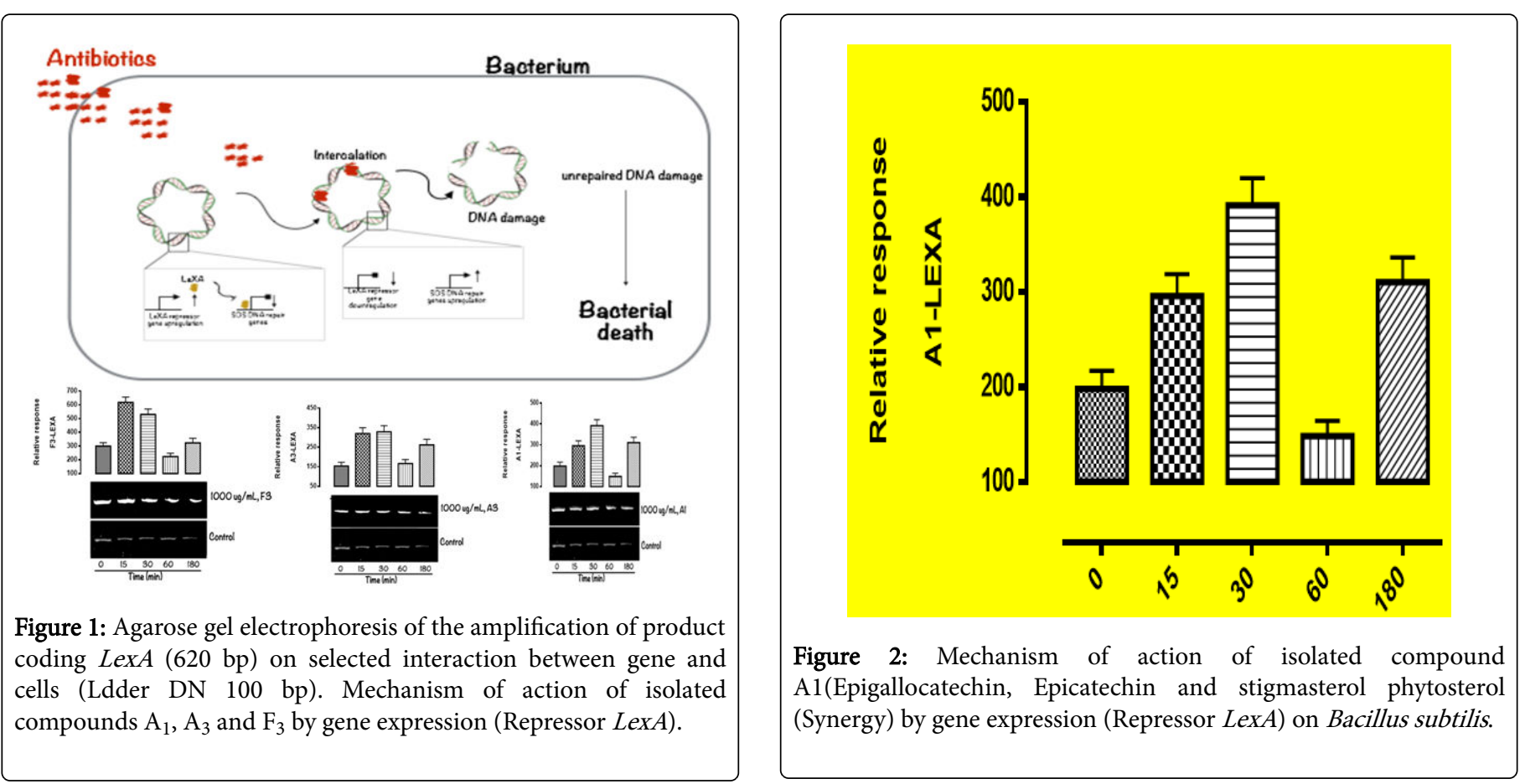
Citation: Osuntokun OT, Omotuyi OI (2018) Bacteriostatic and Bactericidal Mechanism of Novel Compound Isolated from Ethyl Acetate Stem Bark Extract of Spondias mombin Using Biomarker Repressor LexA gene on Escherichia coli and Bacillus subtilis. J Mol Biomark Diagn 9: 405. doi:10.4172/2155-9929.1000405

Page 4 of 7

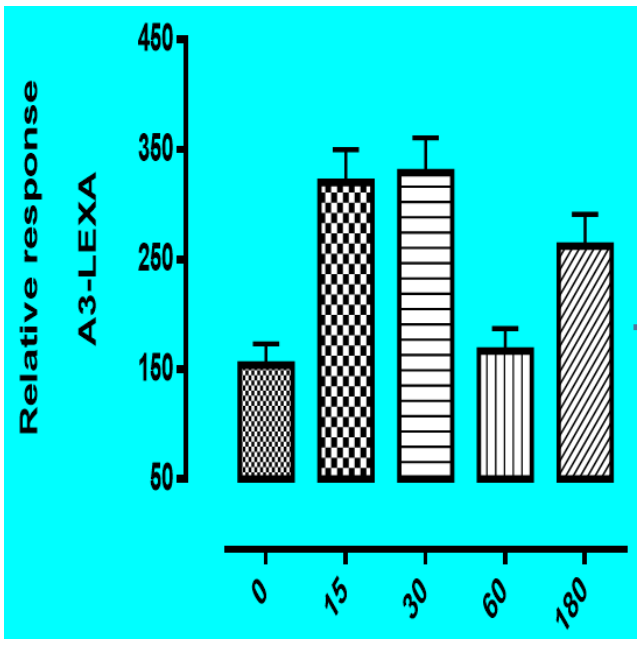

Figure 3: Mechanism of action of isolated compound A3(Aspidofractinine-3-methanol) by gene expression (Repressor LexA) on Bacillus subtilis.

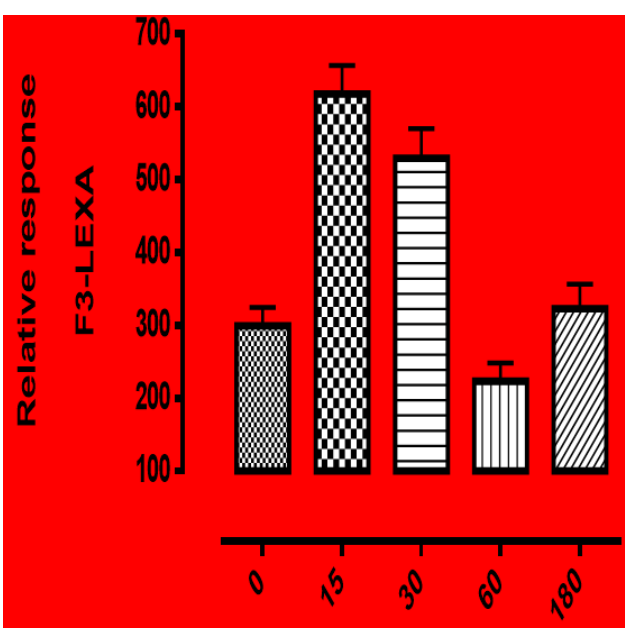

Figure 4: Mechanism of action of isolated compound F3(Terephthalic acid, dodecyl 2-ethylhexyl ester) by gene expression (Repressor LexA) on Bacillus subtilis.

\begin{tabular}{|l|l|}
\hline Target genes or Biomarkers & LexA \\
\hline Forward 5'-3' & GACTTGCTGGCAGTGCATAA \\
\hline Reverse $5^{\prime}-3^{\prime}$ & TCAGGCGCTTAACGGTAACT \\
\hline References & Zehr et al. (2001) \\
\hline
\end{tabular}

Table 2: Primers used for PCR molecular investigation, to determine the mechanisms of action of novel compound isolated from ethyl acetate extract of Spondias mombin on selected clinical organisms.

Figure 5 shows the mechanism of action of isolated compounds $A_{1}$ $\mathrm{A}_{3}$ and $\mathrm{F}_{3}$ from the ethyl acetate stem bark extract of Spondias mombin. It was observed that isolated compounds $A_{1}, A_{3}$ and $F_{3}$ has bactericidal action on $E$. coli at 180 minutes of administration using repressor LexA gene which stimulate the test organism to death phases. The compounds $A_{1}, A_{3}$ and $F_{3}$ disrupt the $S O S$ regulun without activation; the bacteria cells were complete destroyed. This is represented in Figures 5-8. Bactericidal action were observed at 1000 $\mu \mathrm{g} / \mathrm{mL}$ as shown in Figures 5-8 in compound $\mathrm{A}_{1}, \mathrm{~A}_{3}$ and $\mathrm{F}_{3}$ on E. coli.

\section{Discussion}

The purpose of the research work is to determine the mechanism of action of compound A1 (Epigallocatechin, Epicatechin and Stigmasterol Phytosterol (Synergy), $\mathrm{A}_{3}$ (Aspidofractinine-3-methanol) and $\mathrm{F}_{3}$ (Terephthalic acid, dodecyl 2-ethylhexyl ester) with two selected micro-organism. One gram positive, and other gram negative were demonstrated using gene expression, Repressor LexA. All figures describe the mechanism of action of the isolated compound of ethyl acetate stem bark extract of Spondias mombin. In Figure 2, the repressor $\operatorname{Lex} A$ gene was monitored within the time phase of 0 to 180 minutes. It was observed that in $\mathrm{A}_{1}$ LexA activity with Bacillus subtilis shows tremendous interaction between compound $A_{1}, A_{3}$ and $F_{3}$ i.e $\mathrm{A}_{1}$ (Epigallocatechin, Epicatechin and Stigmasterol phytosterol (Synergy), $\mathrm{A}_{3}$ (Aspidofractinine-3-methanol) and $\mathrm{F}_{3}$ (Terephthalic acid, dodecyl 2-ethylhexyl ester). There is a significant and rapid increase to the death phase between 0 to 30 minutes, and a sharp decrease in death phase at 60 minutes but the organism survived at 180 minutes. The same activity was found in relative response of $\mathrm{A}_{3} \operatorname{Lex} A$ and $\mathrm{F}_{3}$ LexA to Bacillus subtilis.

In Figures 1-4, the mechanism of action of compound $A_{1}, A_{3}$ and $F_{3}$ were demonstrated by Repressor LexA gene with Escherichia coli to demonstrate the sequential death phase of the organism between 0-180 minutes time interval. It was observed that $\mathrm{A}_{1}$ Lex $A$ shows a rapid increase in activity between 0 to 180 minutes and at 180 minutes, the organism rapidly enters the death phase, there is an increase in growth at 0 minutes and decrease in growth at 180 minutes i.e the compound completely inhibit the Escherichia coli at 180 minutes. The same activity was found in relative response of $\mathrm{A}_{3} \operatorname{Lex} A$ and $\mathrm{F}_{3} \operatorname{Lex} A$ to Bacillus subtilis.

In Figures 5-8, the mechanism of action of compound $A_{1}, A_{3}$ and $F_{3}$ were demonstrated by Repressor LexA gene with Escherichia coli, to demonstrate the sequential death phase of the organism between 0-180 minutes time interval. It was observed that $\mathrm{A}_{1}$ Lex $A$ shows a rapid decrease in activity from 0 to 180 minutes and 180 minutes the organism rapidly enters the death phase, there is an increase in growth at 0 minutes and decrease in growth at 180 minutes i.e the compound completely inhibit the Escherichia coli at 180 minutes. The same activity was found in relative response of $\mathrm{A}_{3} \operatorname{Lex} A$ and $\mathrm{F}_{3}$ LexA. In $\mathrm{F}_{3}$ LexA, it was a complete inhibition of Escherichia coli at 180 minutes. 
Citation: Osuntokun OT, Omotuyi OI (2018) Bacteriostatic and Bactericidal Mechanism of Novel Compound Isolated from Ethyl Acetate Stem Bark Extract of Spondias mombin Using Biomarker Repressor LexA gene on Escherichia coli and Bacillus subtilis. J Mol Biomark Diagn 9: 405. doi:10.4172/2155-9929.1000405

Page 5 of 7

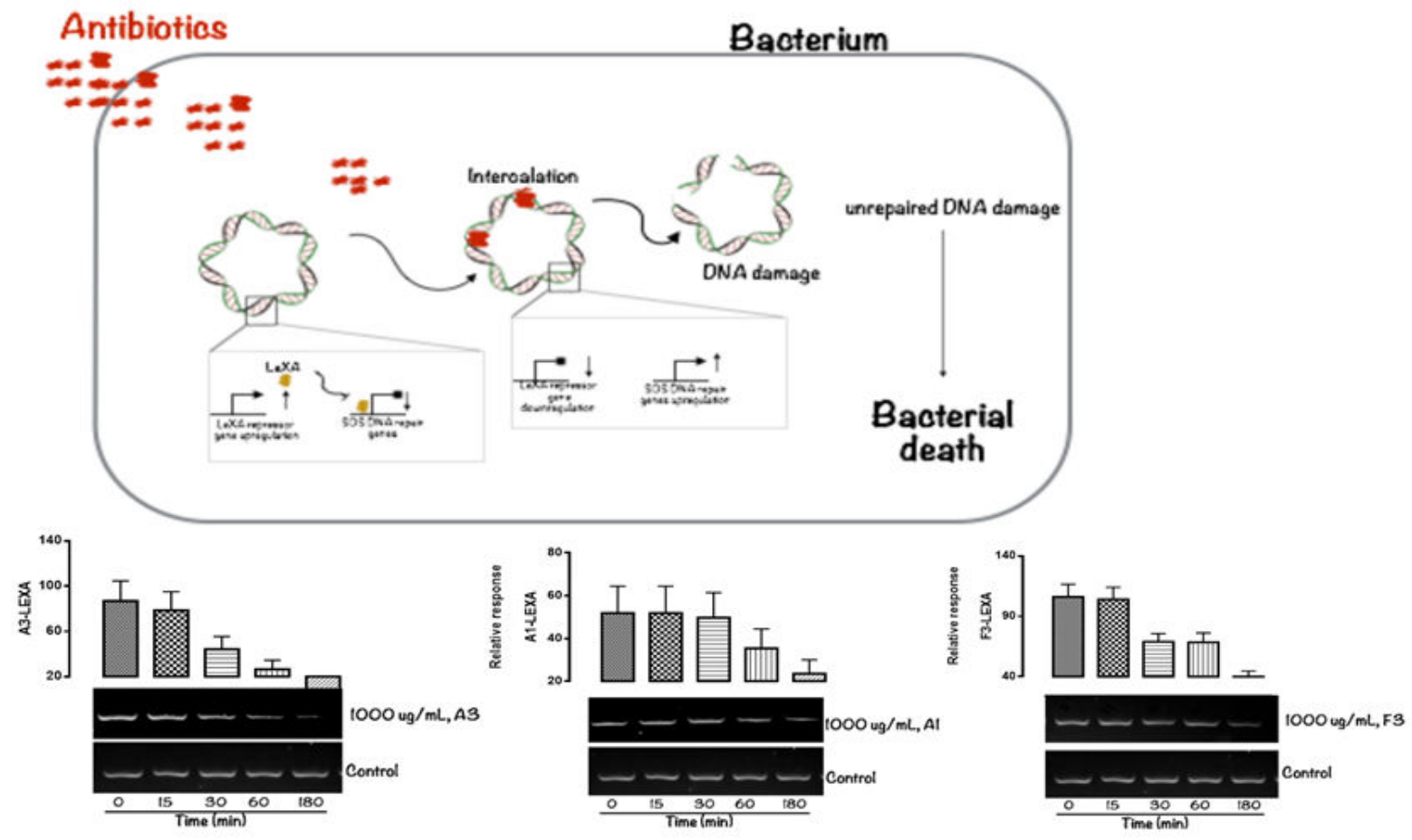

Figure 5: Agarose gel electrophoresis of the amplification of product coding LexA (620 bp) selected interaction between gene and cells (Ldder DN 100 bp). Mechanism of action of isolated compound A1, A3 and F3 by gene expression (Repressor LexA) on Escherichia coli.

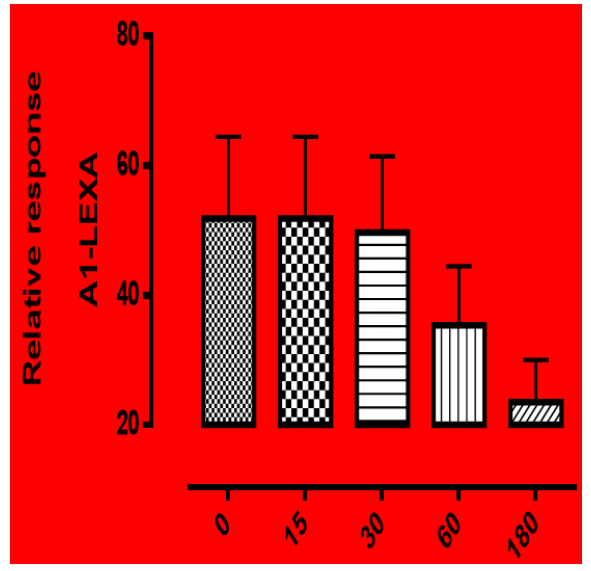

Figure 6: Mechanism of action of isolated compound $\mathrm{A}_{1}$ (Epigallocatechin, Epicatechin and Stigmasterol phytosterol (Synergy)) by gene expression (Repressor LexA) on Escherichia coli.

In evaluating the pathway in Figure 1, the mechanism of $\operatorname{Lex} A$ gene must be discussed for the clarity of purpose. In the presence of single stranded DNA, LexA interacts with $\operatorname{Rec} A$ causing an autocatalytic cleavage which disrupts the DNA binding part of LexA, leading to depression of the SOS repair and eventually DNA repair auto cleavage is maximal at $\mathrm{pH} 11$ in the absence of $\operatorname{Kec} A$ and ssDNA, this activity leads to Ma-1-Gly bond in repressor $\operatorname{Lex} A$ [21]. Erill et al. [7] also reported that repressor $\operatorname{Lex} A$ is a transcriptional repressor that represses SOS response genes coding primarily for error prone DNA polymerase, DNA repair enzymes and cell division. Lex $A$ forms defacto, a two component regulatory system with $\operatorname{Rec} A$ which senses DNA damage at stalled replication fork forming monofilaments and acquiring an active conformation capable of binding to $\operatorname{Lex} A$ and causing Lex $A$ to cleave itself in a process called autoproteolysis [22].

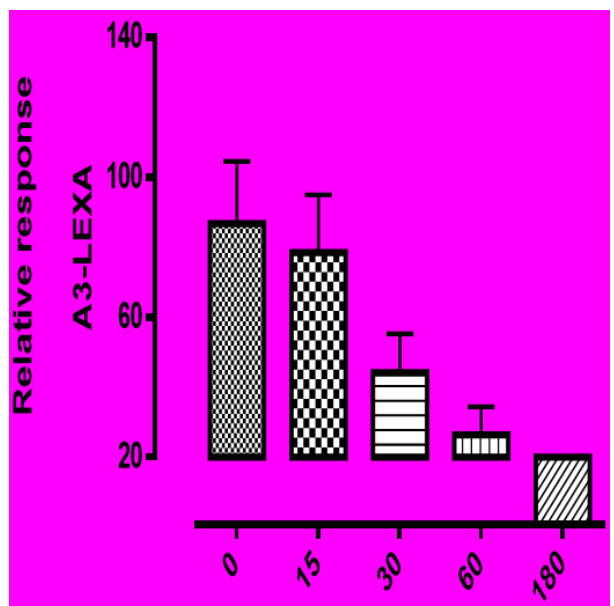

Figure 7: Mechanism of action of isolated compound A3(Aspidofractinine-3-methanol) by gene expression (Repressor LexA) on Escherichia coli. 
Citation: Osuntokun OT, Omotuyi OI (2018) Bacteriostatic and Bactericidal Mechanism of Novel Compound Isolated from Ethyl Acetate Stem Bark Extract of Spondias mombin Using Biomarker Repressor LexA gene on Escherichia coli and Bacillus subtilis. J Mol Biomark Diagn 9: 405. doi:10.4172/2155-9929.1000405

Page 6 of 7

In this research, it was discovered that the effect of the isolated compound from ethyl acetate Spondias mombin extract on the organism can be measured to death phase. If the isolated extract were introduced to the organism i.e E. coli and B. subtilis, it will serve as antibiotics which will cleave the DNA strands of the organism and there are possibilities that the damage is immense through bacteriostatic and bactericidal action. Before the LexA repairs the DNA, the death rate with time can be measured [23]. DNA damage can be created by the action of isolated compound, $A_{1}, A_{3}, F_{3}$, antibiotics, etc. Ubeda et al. [3] reported that bacterial species such as E. coli and B. subtilis require topoisomerases such as DNA gyrase or topoisomerase IV for DNA replication. Isolated compounds $A_{1}, A_{3}$ and $F_{3}$ under the SOS response increase the basal mutation rate of bacteria. Although mutations are often lethal to the cell, they can also enhance survival [24].

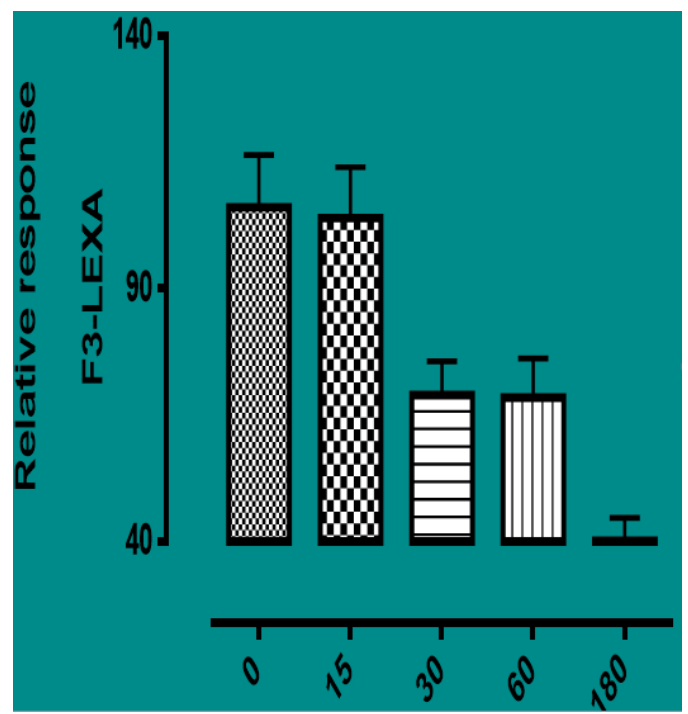

Figure 8: Mechanism of action of isolated compound F3(Terephthalic acid, dodecyl 2-ethylhexyl ester) by gene expression (Repressor LexA) on Escherichia coli.

In Figures 1 and 5, the bacteria (E. coli and B. subtilis) respond to the inclusion of isolated compound thereby leading to the DNA damage, mutation and death of the cell occur but late toward the death phase, the organism survived send a SOS repairs to their DNA, it is shown in the graph that the organism later survive the attack of the isolated compound but part of their DNA were lethally damaged, this account for the increase and decrease of death response with time in the graph in Figures 1-8 respectively. It should be noted that the effects of isolated compound leads to the death of the organism is possible because $\operatorname{Lex} A$ contains a DNA binding domain where the isolated compound can attach itself. The winged HTH motif of LexA is a variant form of the helix-turn DNA binding motif which is usually located at the $\mathrm{N}$-terminus of the protein [20], therefore the mechanism of action of compound $A_{1}, A_{3}$ and $F_{3}$ is by damaging the DNA strands of the organism which leads to the death of the organism, this is demonstrated by the pathway [25].

\section{Conclusion}

In conclusion, the bacteriostatic and bactericidal mechanism of action of Epigallocatechin, Epicatechin and Stigmasterol phytosterol (Synergy), Aspidofractinine-3-methanol) and Terephthalic acid, dodecyl 2-ethylhexyl ester were measured by selective biomarker and gene expression, repressor LexA on Escherichia coli and Bacillus subtilis. It was observed that $\operatorname{Lex} A$ gene increase a rapid progress of organisms to sequential dormancy and death phase with time interval, this led to the death of the bacteria cell, it can be deduced that, this method can be used to program the death of bacteria cell in case of a recalcitrant infections.

It is thereby recommended that the medicinal plant such as Spondias mombin and other types of medicinal plants should be studied and exploited for future use.

\section{References}

1. Erill I, Campoy S, Barbe J (2007) Aeons of distress: An evolutionary perspective on the bacterial SOS response. FEMS Microbiol Rev 31: 637-656.

2. Butala M, Zgur-Bertok D, Busby SJ (2009) The bacterial LexA transcriptional repressor. Cell Mol Life Sci 66: 82-93.

3. Ubeda C, Maiques E, Knecht E, Lasa I, Novick RP, et al. (2005) Antibiotic-induced SOS response promotes horizontal dissemination of pathogenicity island-encoded virulence factors in staphylococci Mol Microbiol 56: 836-844.

4. Beaber JW, Hochhut B, Waldor MK (2004) SOS response promotes horizontal dissemination of antibiotic resistance genes. Nature 427: 72-74.

5. Guerin E, Cambray G, Sanchez-Alberola N, Campoy S, Erill I, et al. (2009) The SOS response controls integron recombination. Science 324: 1034.

6. Ayoka AO, Akomolafe RO, Akinsomisoye OS, Ukponmwan OE (2008) Medicinal and economic value of Spondias mombin. Afr J Biomed Res 11: $129-136$.

7. Rodrigues KF, Samuels GJ (1999) Fungal endophytes of Spondias mombin leaves in Brazil. J Basic Microbiol 39: 15-18.

8. Rodrigues KF, Hasse M (2000) Antimacrobial activities of secondary metabolites produced by endophytic fungi from Spondias mombin. J Basic Microbiol 40: 261-267.

9. Nworu CS, Akah PA, Okoye FB, Toukam DK, Udeh J, et al. (2011) The leaf extract of Spondias mombin L. displays an anti-inflammatory effect and suppresses inducible formation of tumor necrosis factor- $\alpha$ and nitric oxide (NO). J Immunotoxicol 8: 10-16.

10. Villegas LF, Fernadz TD, Maldonado H, Torres R, Zavaleta A, et al. (1997) Evaluation of wounds healing of selected plants from Peru. J Ethnopharmacology 55: 193-200.

11. Osuntokun OT, Oluduro AO, Idowu TO, Omotuyi AO (2017) Assessment of nephrotoxicity, anti-inflammatory and antioxidant properties of epigallocatechin, epicatechin and stigmasterol phytosterol (Synergy) derived from ethyl acetate stem bark extract of Spondias Mombin on wistar rats using molecular method of analysis. J Mol Microbiol 1: 103.

12. Temitope OO, Ogunmodede AF, Fasusi OA, Thonda AO, Odufunwa AE (2017) Synergistic antibacterial and antifungal activities of Spondias mombin extracts and conventional antibiotic and antifungal agents on selected clinical microorganisms. Sch J App Med Sci 5: 307-318.

13. Cirz RT, Chin JK, Andes DR, De Crécy-Lagard V, Craig WA, et al. (2005) Inhibition of mutation and combating the evolution of antibiotic resistance. PLoS biology 3: e176.

14. Janssen PH, Kirs M (2008) Structure of the archaeal community of the Rumen. Appl Environ Microbiol 74: 3619-3625.

15. Babu PV, Liu D, Gilbert ER (2013) Recent advances in understanding the anti-diabetic actions of dietary flavonoids. J Nutr Biochem 24: 1777-1789. 
Citation: Osuntokun OT, Omotuyi OI (2018) Bacteriostatic and Bactericidal Mechanism of Novel Compound Isolated from Ethyl Acetate Stem Bark Extract of Spondias mombin Using Biomarker Repressor LexA gene on Escherichia coli and Bacillus subtilis. J Mol Biomark Diagn 9: 405. doi:10.4172/2155-9929.1000405

Page 7 of 7

16. Lin-Chao S, Bremer H (1986) Effect of the bacterial growth rate on replication control of plasmid pBR322 in Escherichia coli. Mol Gener Geneti 203: 143-149.

17. Walley JW, Coughlan S, Hudson ME, Covington MF, Kaspi R, et al. (2007) Mechanical stress induces biotic and abiotic stress responses via a novel cis-element. PLoS Genet 3: 1800-1812.

18. Halliwell B (2008) Are polyphenols antioxidants or pro-oxidants? What do we learn from cell culture and in vivo studies?. Arch Biochem Biophy 476: 107-112.

19. Newman DJ, Cragg GM, Snader KM (2000) The influence of natural products upon drug discovery. Nat Prod Res 17: 215-234.

20. Scalbert A, Manach C, Morand C, Rémésy C, Jiménez L (2005) Dietary polyphenols and the prevention of diseases. Crit Rev Food Sci Nutr 45 287-306.
21. Yehuda C, Castro J, Eliopoulos GM, Samore MH (2001) Clinical isolation and patterns of and super infection with 10 nosocomial pathogens after treatment with ceftriaxone Vs. ampicillin-sulbactam. Am Soc Microbiol 45: 275-279.

22. Warren GL, Andrews CW, Capelli AM, Clarke B, LaLonde J, et al. (2006). A critical assessment of docking programs and scoring functions. J Med Chem 49: 5912-5931.

23. Walters W, Stahl M, Murcko M (1998) Virtual screening: An overview. Drug Discov Today 3: 160-178.

24. Tilburt JC, Kaptchuk TJ (2008) Herbal medicine research and global health: an ethical analysis. Bull World Health Organ 8: 577-656.

25. The Japanese Pharmacopeia (2001) Fourteenth edition, JP XIII. The Society of Japanese Pharmacopeia, Japan. 